\title{
Nest-site selection and population trend of Collared Pratincoles (Glareola pratincola) breeding in agricultural habitats of the Nagykunság region (Hungary)
}

\author{
Ádám KIss*, Ákos MonoKI \& Zsolt VÉGVÁRI
}

Received March 24, 2017 - Accepted May 12, 2017

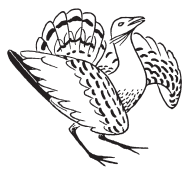

Kiss, Á., Monoki, Á. \& Végvári, Zs. 2017. Nest-site selection and population trend of Collared Pratincoles (Glareola pratincola) breeding in agricultural habitats of the Nagykunság region (Hungary). - Ornis Hungarica 25(1): 25-38. DOI: 10.1515/orhu-2017-0002 peared from the traditional grassland breeding sites before the 2000 and is currently breeding only in three sites in agricultural environments in Hungary. The objectives of our research were to find links between the use of shallow wetlands and the breeding behaviour of the species and to identify the characteristics of its breeding on ploughed fields. Data were collected between 2008 and 2016 as part of preparations for the conservation of the largest population which is found in the Nagykunság. We found a positive correlation between colony size and the area of the nearby wetland. We calculated the proportion of habitat-types used for nesting, and found that cultivated fields and fallow lands were the most important. Additionally, we also found that colony sizes were substantially smaller during the research period than those found earlier in the traditional grassland habitats. Finally, we found a positive trend in the size of the population during the research period.

Keywords: R, ARCGIS, agricultural breeding habitat, crop type, Collared Pratincole conservation management, nest site selection

Összefoglalás Az egykor az Alföld szikes pusztáin költő székicsér mára kipusztulással közvetlenül fenyegetett madárfaj lett hazánkban. A tradicionálisnak számító pusztai élőhelyeiről az ezredforduló előtt teljesen eltünt, és évtizedek óta kizárólag csak mezögazdasági környezetben költ. Jelenleg három területen fészkel az országban. A 2008 és 2016 közötti időszakban vettünk fel adatokat a legnagyobb méretű nagykunsági populáció védelmének szervezése során. Kutatásunk célja az volt, hogy kapcsolatot keressünk a sekélyvizes élőhelyek és a székicsérek költési szokásai között, valamint megállapítsuk a szántóföldi fészkelések jellemzőit. A kolóniát alkotó párok száma és a közeli vizes élőhely mérete között pozitív korrelációt találtunk. Meghatároztuk a székicsérek által költésre leggyakrabban használt élőhelytípusok arányát, melyekben a kapáskultúrák és az ugaroltatott területek voltak a legjellemzőbbek. A költőtelepek méreteit is rögzítettük, mely során azt állapítottuk meg, hogy a vizsgálati idöszakban tapasztalt telepméretek lényegesen kisebbek a tradícionális élőhelyekre jellemzőknél. Meghatároztuk a mintavételi időszakot érintő állományváltozás pozitív irányú trendjét.

Kulcsszavak: R, ARCGIS, mezőgazdasági fészkelőhelyek, szántóföldi kultúra-típus, székicsér fajvédelem, fészkelőhely-választás

Department of Conservation Zoology, Hortobágy National Park Directorate - University of Debrecen, 4024 Debrecen, Sumen utca 2., e-mail: kissadam@hnp.hu

*correspondig author 


\section{Introduction}

The Collared Pratincole is distributed in the Indo-African biogeographical region and is divided into three known subspecies. The world population is estimated to $160.000-600.0000$ individuals (Wetlands International 2015), while the European population includes 7.80014.900 pairs (Birdlife International 2015). The nominate race G. p. pratincola breeds in Europe and Asia (Tucker et al. 1994). Although the world population is not endangered, the species shows a declining trend in its entire distribution area (Wetlands International 2015). The European population has a highly fluctuating trend (Birdlife International 2015).

The range of the nominate race in the Western Palearctic extends from the Iberian Peninsula across the Carpathian Basin to the Caspian region, and its breeding habitat includes saline steppes, steppes and semideserts (Hayman et al. 1991). Nesting in agricultural landscapes has been detected in a number of European countries in the 1980s and the 1990s (Calvo \& Alberto 1990, Kayser 2015).

In Spain, population decline due to habitat loss has been identified during the early 1990s. In the Sevilla region, $62 \%$ of the breeding pairs were found in fallow and arable lands. The majority of the colonies in agricultural areas were located in sunflower and cotton fields and occasionally in sorghum and chickpea cultivations (Calvo \& Alberto 1990). However, breeding success was substantially lower as compared to in fields than in grasslands close to seminatural marshlands (Calvo 1994).

Studies conducted on the nest site selection of waders breeding in agricultural landscapes in Western Russia found that the Collared Pratincole breeding in agricultural areas is one of the most vulnerable waders (Lebedeva 1998).

In France, the majority of the population is located in the Camargue region. As the number of pairs fluctuated between 37-127 in the period of 2004-2014, this population is considered as threatened. Nests in agricultural areas were mostly found in maize and sorghum plantations (Kayser 2015). In Montenegro, 70-80 pairs of Collared Pratincoles breed in dry salinas close to Ulcinj (Saveljic 2002).

The populations of Collared Pratincole experienced a dramatic decline in the last ten years and is one of the waders that are close to local extinction in Hungary. Other species that experienced similar declines due to gradual habitat loss and fragmentation, disappearance of wetlands and collapse of grazing livestock include the Kentish Plover (Charadrius alexandrinus) and the Stone Curlew (Burhinus oedicnemus) (Rakonczai et al. 1989).

In the $19^{\text {th }}$ century, the species was still considered as a widely distributed bird in the entire Great Hungarian Plain, and there were also colonies in Transdanubia (Chernel 1899). In contrast, in the $20^{\text {th }}$ century, colonies were known only in areas between the rivers Danube and Tisza, in Hortobágy, Nagykunság and in Békés County. In Hortobágy, where the most significant populations bred in the early 1990, the total population amounted to 500 pairs (Kovács \& Kapocsi 2005). For example, in August 1942, 150 individuals were observed in the vicinity of Hajdúböszörmény, which might have consisted of birds from the Hortobágy population during their pre-migratory aggregation. The Hortobágy population amounted to 180-200 pairs during the 1960s and 150-160 pairs during the 1970s (Kovács \& Kapocsi 2005). 
Within Horotbágy the largest colonies were found near Kunmadaras in the 1960s and 1980s, predominantly close to Csíkos and Mérges Marshes, in Bogárzó, close to Döghalom and Gyúró-kút areas (Szabó 1980). Further, pratincoles regularly bred in Nagyiván, Nyírö-lapos, Nyári-járás, Máta, Angyalháza, Zám and Szelencés areas. Traditional colonies survived in declining numbers during the early 1980s (Kovács \& Kapocsi 2005).

Colonies in the eastern Hortobágy (Nyári-járás, Angyalháza, Szelencés areas) were lost until 1985, and a few breeding sites remained in the southern areas (Kovács 1993). From 1980 onwards, the Hortobágy population totalled up to 100 pairs in the best years but experienced its final declining stage which included less than 50 pairs in later years (Kovács 1993). In the 1990s, pratincoles ceased to breed in the Kunmadaras area, with only occasional breeding activities (Kovács \& Kapocsi 2005). Nest sites were known in the Kecskeri area 20 kilometres from Kunmadaras area during the 1980s and 1990s (Endes 1991).

Similarly to the processes observed in Hortobágy, pratincoles also suffered a drastic population decline in the Kiskunság region. In the 1970s, colonies of up to 30-40 pairs regularly formed in Kelemen-szék and Kis-rét marshes. In the 1980s, colonies of Apaj and Ürbő significantly decreased and then disappeared from salt pans of Upper Kiskunság (Bankovics et al. 2015). In later years, only occasional breeding activities were observed in the region. In 1992, a nest with a single egg was observed in an overgrazed grassland plot in Harta-Akasztó area (Berdó 1992). At the turn of the century, a brood with two young was found in Kelemen-szék marsh (Pigniczki 2000).

Similarly to the Hortobágy and Kiskunság populations, those of Békés County also have dramatically declined, and only pairs breeding in agricultural landscapes survived (Széll 1996). In the 1930s, a flock showing nest protection behaviour was spotted in the alkali steppe of Csudaballa, located in between Túrkeve and Gyomendrőd (Tarján 1934). Breeding pratincoles were known in the Kóré-zug area in Dévaványai-Ecsegi steppes in the early 1990s (Széll 1996). In 1993, a colony of 2-3 pairs was observed in a dry pond of the Fertö Fishponds of Szentes (Bod 1993).

The characteristic breeding habitat of the Collared Pratincole included steppes interspersed with temporarily flooded wetlands (Széll 2014). In Hortobágy, pratincoles nested in areas with sporadic vegetation intensively grazed by cattle, in the vicinity of grazed and open-water salt pans as well as wet grasslands. Nest-sites were chosen in dry Puccinellietum wetlands grazed by cattle and also in barren plots of Camphorosmetum, Spergularia, Pholiurus and Plantago tenuiflora vegetation (Szabó 1980).

Eggs were often laid on dry cattle dung or in cattle footprints, often in nest cups lined with plant material. Occasionally, Collared Pratincoles bred in barren edges of excavations, planed rice-field dykes, abandonded livestock roosts, boundaries of salt pans as well as in areas surrounding duck farms covered by dry manure layers (Szabó 1980). At the turn of the century, a pair of pratincoles successfully bred in a mudflat during emergency floods in 1999 and 2000 (Kovács \& Kapocsi 2005).

In the 1980s, the number of surviving colonies in native grasslands started to decline heavily and completely disappeared during the early 1990. This population collapse was probably due to the gradual decline of livestock grazing and the disappearance of wetlands as a result of the establishment of irrigation canal networks (Kovács \& Kapocsi 2005). In 
parallel to the intensive decline of livestock grazing, especially that of cattle, populations declined and disappeared in alkali grasslands (Sterbetz 1974). Following declining population trends, colonies were found increasingly often in intensively cultivated arable and fallow lands. Since 1994, Collared Pratincoles have bred only in these types of habitats (Oláh \& Széll 1994).

However, colonies breeding in arable lands were first detected a lot earlier: in 1902, a colony of five pairs were found in a carrot field in the Great Hungarian Plain and in 1906, a colony of a few pairs were observed in a feed-corn field. In 1919, birds showing nest protection behaviour were found in a fallow land. Later, a colony consisting of a minimum of three pairs were found, and the eggs from the nest were collected (Cerva 1926).

Breeding activities in agricultural areas were reported close to Zádor-lapos, Asszonyszállás, Kunlapos from 1980 onwards, from 1985 onwards in the vicinity of Mezötúr, in Csabacsüd in 1987 and in Szarvas and Ecsegfalva in 1988 (Széll 1993). In 1994, two colonies were found in maize fields in Kiskunlacháza (Selmeczi-Kovács 1994), and 82 pairs bred in three agricultural regions of the Great Hungarian Plain (Oláh \& Széll 1994). In 1996, two early-phase colonies were discovered in a sunflower field in Kunlapos area near Karcag (Kapocsi 2002).

Agricultural habitats are now considered as vital for the nesting of Collared Pratincoles. A special focus is given to flooded and fallow rice fields as well as sunflower and maize plantations (Csíder 2008). In the past 20-25 years Collared Pratincoles almost exclusively bred in the vicinity of rice fields in eastern Hungary, with a few occasional exceptions. In 1994, breeding pairs were located in flooded rice plantations in neighbourhoods of Csabacsüd, Karcag, Kisújszállás, Mezőtúr and Szarvas (Oláh \& Széll 1994). Studies carried out on nest site conditions and distance to the nearest water body concluded that the height of rice amounts to 3-4 cm during the initial phase of breeding, thus forming adequately sparse vegetation. Nests were 0.1-2 kilometres away from water bodies (Széll 1993). Collared Pratincoles breeding in root crops regularly hunt in the close neighbourhood of the colony, occasionally in nearby cereal fields (Kiss 2011).

The aim of this study was to present data on the status of the largest, Nagykunság population of Collared Pratincoles and to identify environmental factors related to the nest site selection of Collared Pratincoles. We specifically considered four factors: (1) physical characteristics of nearby wetlands (2), type of arable field (3), characteristics of alkali soil plots, and (4) proportion of crop types in the landscape. Additionally, we aimed to estimate colony size and proportion in agricultural areas. Finally, we provide an estimation of the short-term population trend of Collared Pratincoles in the Nagykunság region.

\section{Materials and Methods}

Our study area comprised all known pratincole habitats in the administrative districts of Karcag, Kisújszállás and Ecsegfalva, which extend to a total of 33,144 hectares (Figure 1). Within this region, we identified the following habitat types (in order of decreasing proportion in the landscape): arable lands, rice fields, marshes and extensively managed grasslands. 


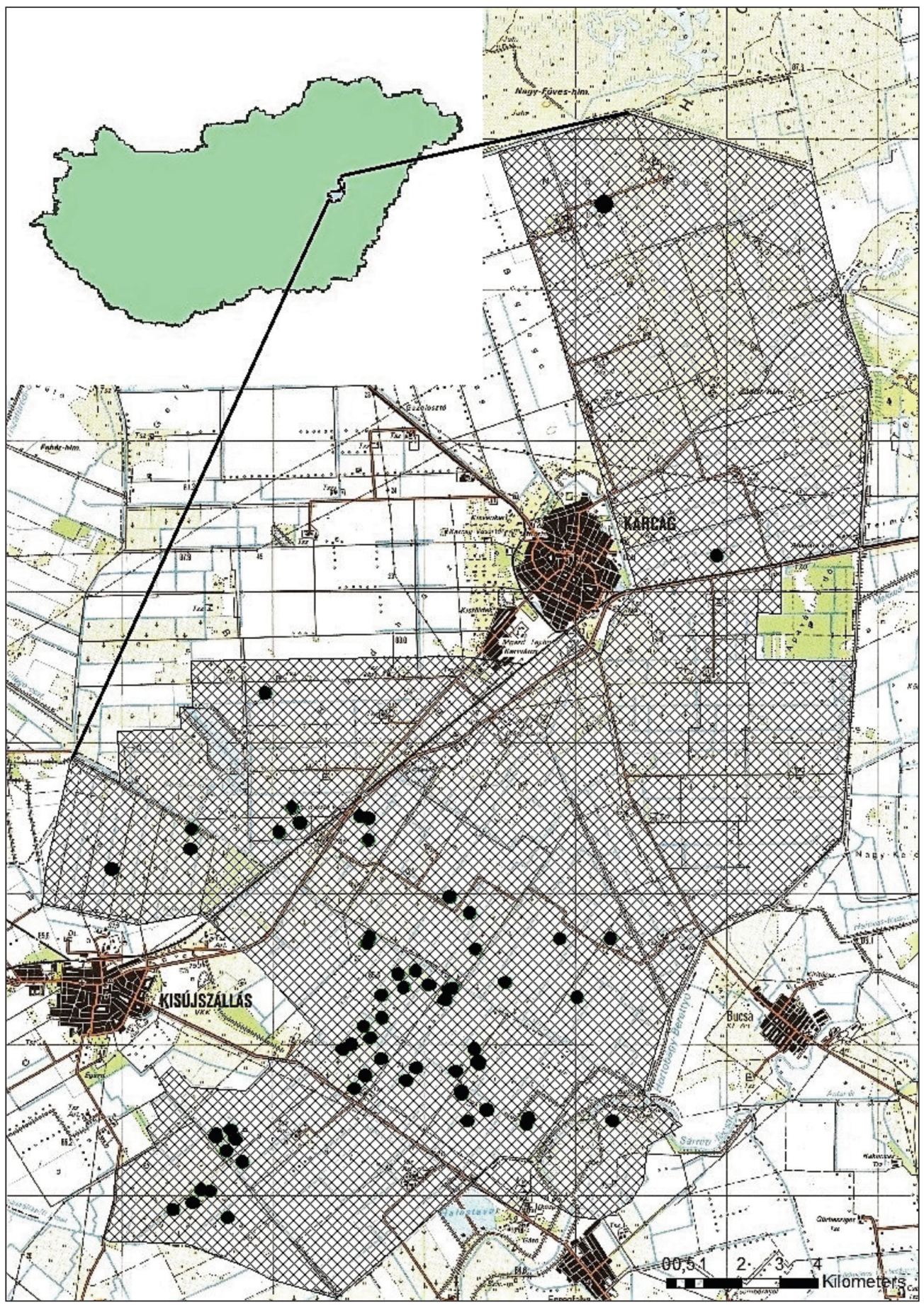

Figure 1. Location of the study area and colonies monitored between 2008 and 2016

1. ábra A vizsgálati terület átnézeti képe 2008-2016 között a költőállományok pontjaival 
Breeding activities were also regularly recorded in the following areas near Karcag in the 1990s and early 2000s: Kunlapos, Bengecseg, Apavára, Botonás (Kapocsi 2002). In these areas we found only occasional breeding activities in the study period, which we less frequently but regularly monitored. Focal searches of Collared Pratincoles were conducted in rice fields, arable lands and in their $2 \mathrm{~km}$ surrounding. Focal areas were surveyed several times a week.

Surveys of potential nest sites where pratincoles were prospecting in agricultural areas were already started during the spring migration period. Nest sites were determined based on the behaviour of birds that showed exploratory flights and colony establishment activities (Kovács \& Kapocsi 2005). Searches for incubating birds were initially conducted in the boundary zone of the field hosting the colony, and were later extended to areas within the particular field to precisely locate nests.

Because incubating birds generally tolerate agricultural machines around the colony, nests with eggs could be easily located from 4WD cars. When we visited nests, breeding pairs were only disturbed during the short interval of recording GPS coordinates, nest parameteres (site, egg numbers) and taking photos. We considered a location to be a nest site if it was occupied by a nest at least once.

When we found nests with young, we recorded pointing coordinates in the EOV coordinate system. All nest locations and history were recorded in a control log, which contained information on date, site ID and coordinates of locations, nest status, number of eggs/ young, number of succesfully hatched young as well as the cause of breed failure if applicable. Using the coordinates of located nests, we generated a point layer of nests and colonies using ARCMAP 10.1 software for spatial analysis.

To analyse nest site choice, we employed three response variables: (1) number of pairs, (2) number of successfully breeding pairs, and (3) proportion of successfully breeding pairs for each colony. We used crop type, the distance and size of the nearest shallow wetland, and the distance of the nearest alkali soil patch as predictors. We applied linear mixed models, entering year as random term, using the ,Ime4” package in the R statistical programming environment (R Development Core Team 2016). Additionally, we tested whether the distance of nearest neighbours within colonies was related to habitat type, by applying Kruskal-Wallis-test.

During nest search we also determined colony size. We considered a breeding pair to be colonial if the disturbance experienced by the nesting pair has evoked nest protecting behaviour in pratincoles in neighbouring areas. Additionally, we collected colony sizes found since 2008 and compared their frequencies in various crop types. Finally, each breeding season, we estimated the total size of the breeding population of the region by considering the numbers of both first and replacement clutches.

\section{Habitats}

During the study period, we identified and estimated the size and location of natural as well as artificially flooded wetlands. Agricultural habitats used by pratincoles were classified into four categories, based on soil preparation, timing of crop sowing and technology. 


\section{Root crops}

This class includes crops sown between mid-April to early May. Soil settlement following basic cultivation is carried out in the spring before seedbed preparation with disc, harrow, roller and other machinery. Following seedbed preparation, bare soil surface of small grain size is formed which is sufficiently compressed in seed depth and only covered by straw. This type is characterised by large row distances, ranging between 70 and $76 \mathrm{~cm}$ (Csajbók 2012). This habitat class is represented by sunflower, maize and sorghum in the region.

\section{Spring cereals}

This type is represented by oat sown in March and April, which starts to grow only late as a result of soil and precipitation conditions, generally during the spring arrival of pratincoles. In lower-lying areas with longer water cover, this crop does not germinate, leaving barren alkali spots behind.

\section{Early summer crops}

This class includes crops sown late, in May or June. In the Nagykunság region, this type is represented by alfalfa, Alexandria clover and millet. Early summer crops play an important role as green fertilizers of fallow white rice fields. These crops are sown into small-grain settled seedbank, similar to cereal sowing (Csajbók 2012). This habitat class is occupied by pratincoles during barren, early developmental stages, prior to germination.

\section{Fallow land}

These fields are abandoned for cultivation for a year, managed by heavy discs once or twice a year between early- and mid-May. Fallow lands are mostly represented by fallow white rice fields in the region. Cultivation technology of white rice requires crop alternation (Sárvári 2011). Owing to discing, the soil will be smaller-grained.

\section{Results}

\section{Nest site selection}

During the study period (2008-2016), we found 258 breeding events in colonies or solitary pairs (Figure 2). The proportions of breeding events in various habitat types are summarised in Table 1.

Out of the three models, the only significant relationship was a positive relationship between the number of pairs and the size of nearest wetland: larger water bodies predicted colony size defined as the number of nesting pairs $(b=0.006, t=2.328)$. None of the predictors in the two other models had significant effects on any of the response variables ( $p>0.323$ for all cases) (Figure 3 ). 


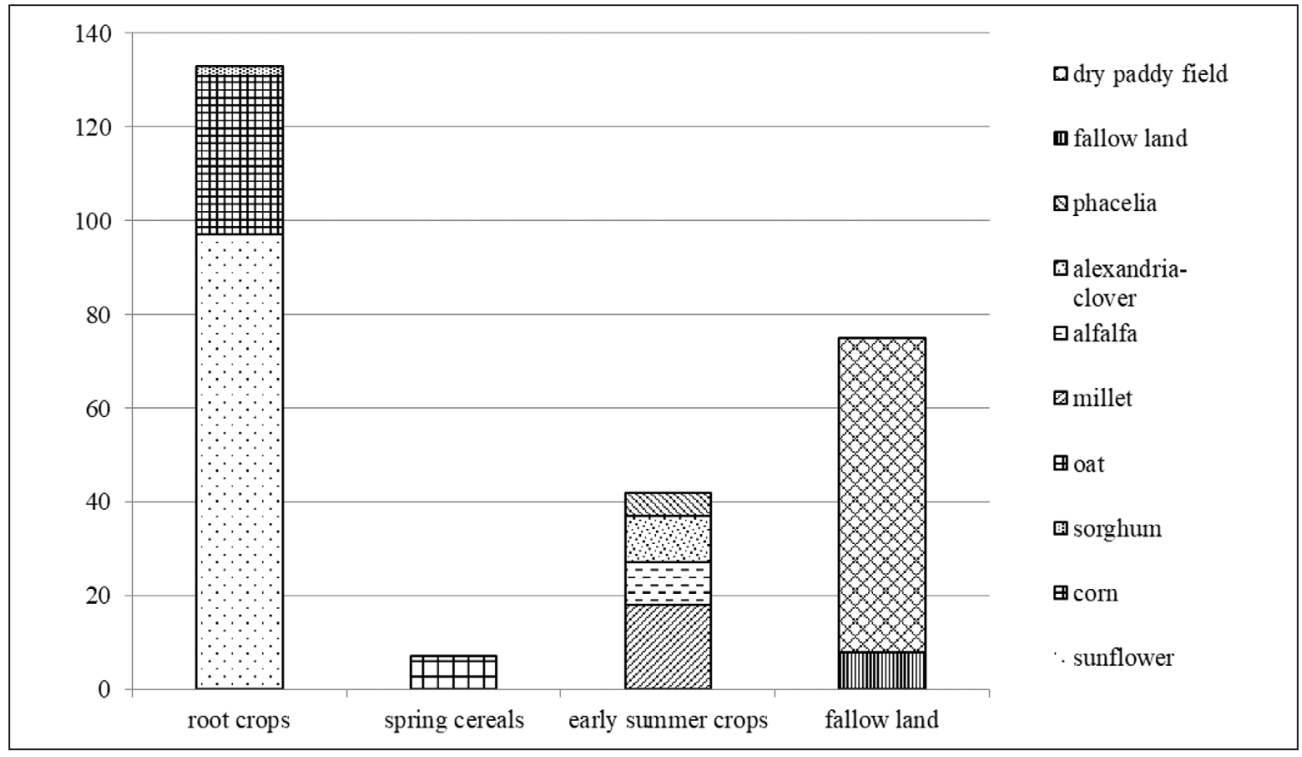

Figure 2. The number of nests in different in agricultural crops during the study period 2. ábra Az agrár-élőhelyek foglalási aránya a mintavételi időszakban

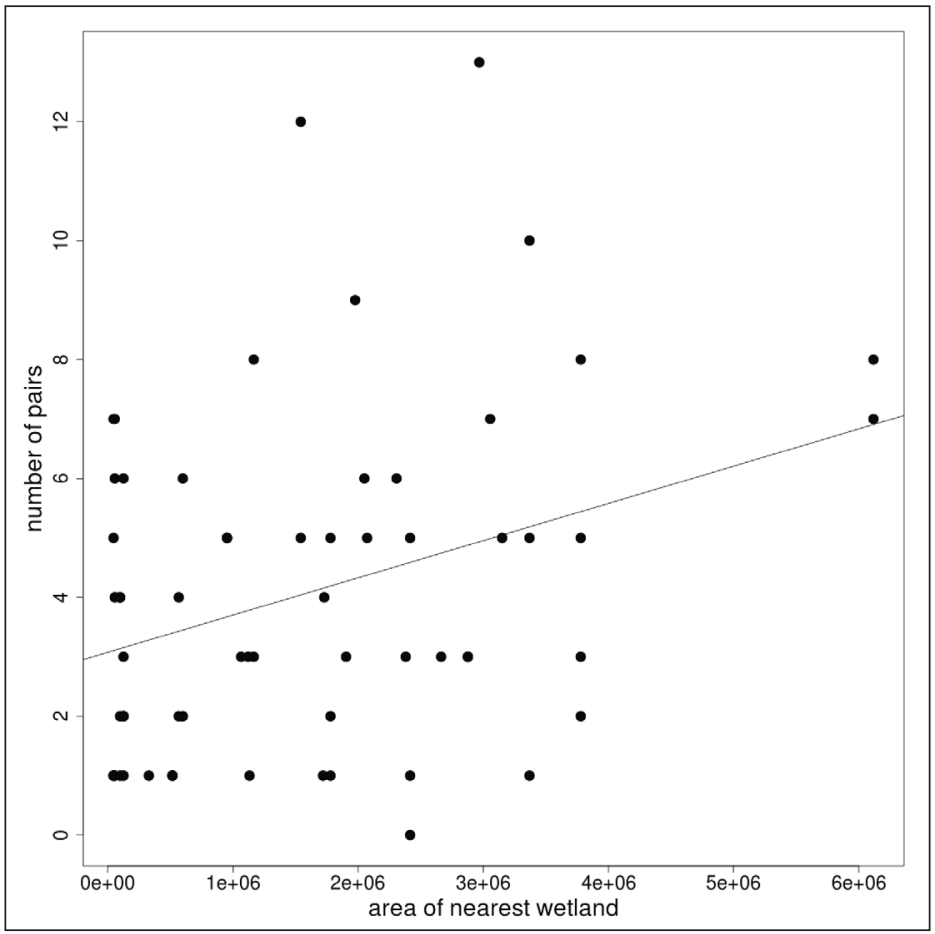

Figure 3. The number of breeding pairs as a function of the area of the nearest wetland (in $\mathrm{m}^{2}$ )

3. ábra Telepalkotó párok számának növekedése a legközelebb lévő sekélyvizes élőhely méretével arányosan 
Table 1. Colony sizes and frequency of their occurrences in various crop types

1. táblázat Székicsér-kolóniák méretei, illetve előfordulásuk arányai a különböző élőhelytípusokban

\begin{tabular}{|c|c|c|c|c|c|}
\hline $\begin{array}{c}\text { Size of colony } \\
\text { (number of } \\
\text { pairs) }\end{array}$ & $\begin{array}{c}\text { Number of } \\
\text { occurence }\end{array}$ & $\begin{array}{c}\text { Occurence } \\
\text { in cultivated } \\
\text { lands (\%) }\end{array}$ & $\begin{array}{c}\text { Occurence in } \\
\text { spring seeding } \\
\text { lands (\%) }\end{array}$ & $\begin{array}{c}\text { Occurence in } \\
\text { summer seeding } \\
\text { lands (\%) }\end{array}$ & $\begin{array}{c}\text { Occurence in } \\
\text { fallow lands (\%) }\end{array}$ \\
\hline 13 & 1 & 100 & 0 & 0 & 0 \\
\hline 12 & 1 & 100 & 0 & 0 & 0 \\
\hline 11 & 0 & 0 & 0 & 0 & 0 \\
\hline 10 & 1 & 0 & 0 & 0 & 100 \\
\hline 9 & 1 & 0 & 0 & 0 & 100 \\
\hline 8 & 3 & 66.6 & 0 & 33.3 & 0 \\
\hline 7 & 4 & 75 & 0 & 0 & 25 \\
\hline 6 & 5 & 40 & 20 & 20 & 20 \\
\hline 5 & 10 & 40 & 0 & 0 & 60 \\
\hline 4 & 5 & 20 & 20 & 40 & 20 \\
\hline 3 & 10 & 60 & 0 & 20 & 20 \\
\hline 2 & 8 & 50 & 0 & 25 & 25 \\
\hline Solitary pairs & 13 & 54 & 0 & 23 & 23 \\
\hline
\end{tabular}

The mean distance to nearest neighbours calculated for each colony did not differ between habitat types (Kruskal-Wallis $\chi^{2}=5.290, \mathrm{df}=9, \mathrm{p}=0.8084$ ).

Out of the four habitat types, occupancy rates were the largest for root crops $(52 \%)$ and fallow lands (29\%). While $16 \%$ of nests were found in fields of crops sown during early summer, this number amounted only to $3 \%$ in spring sown crops (Figure 2).

\section{Characteristics of colonial breeding}

Mean colony size was 4.94 pairs/colony ( $n=49$ colonies). More than half $(67 \%)$ of colonies consisted of 2-5 pairs. The largest colonies, consisting of 7-13 pairs were established mostly in root crops (64\%), fallow lands (28\%) and rarely in early summer crops (8\%) (Table 1).

We found colonies consisting of more then 11 pairs only in two occasions. In 2015, a colony of 13 pairs were found in Kisrét of Kisújszállás, while a colony of 12 pairs was established in Gyalpár in the same region. The proportion of colonies consisting of 10 or more pairs was thus substantially smaller (6.1\%) than the proportion of smaller colonies $(93.9 \%)$.

Solitary breeders made up $21 \%$ of all nesting records. More than half of the solitary nesting pairs were located in root crops.

\section{Trend of the Nagykunság population between 2008-2016}

The minimum population size was found in 2008 with only 15 breeding pairs in the region. In contrast, the maximum population size was in 2016 with 36-37 pairs. During the study period, both the number of pairs and number of clutches increased. Total population size increased significantly in the region between 2008-1016 (Figure 4) (linear regression, b=2.00, $\mathrm{df}=7, \mathrm{p}=0.002$ ) although the increase was smaller before the peak year of 2016 . 


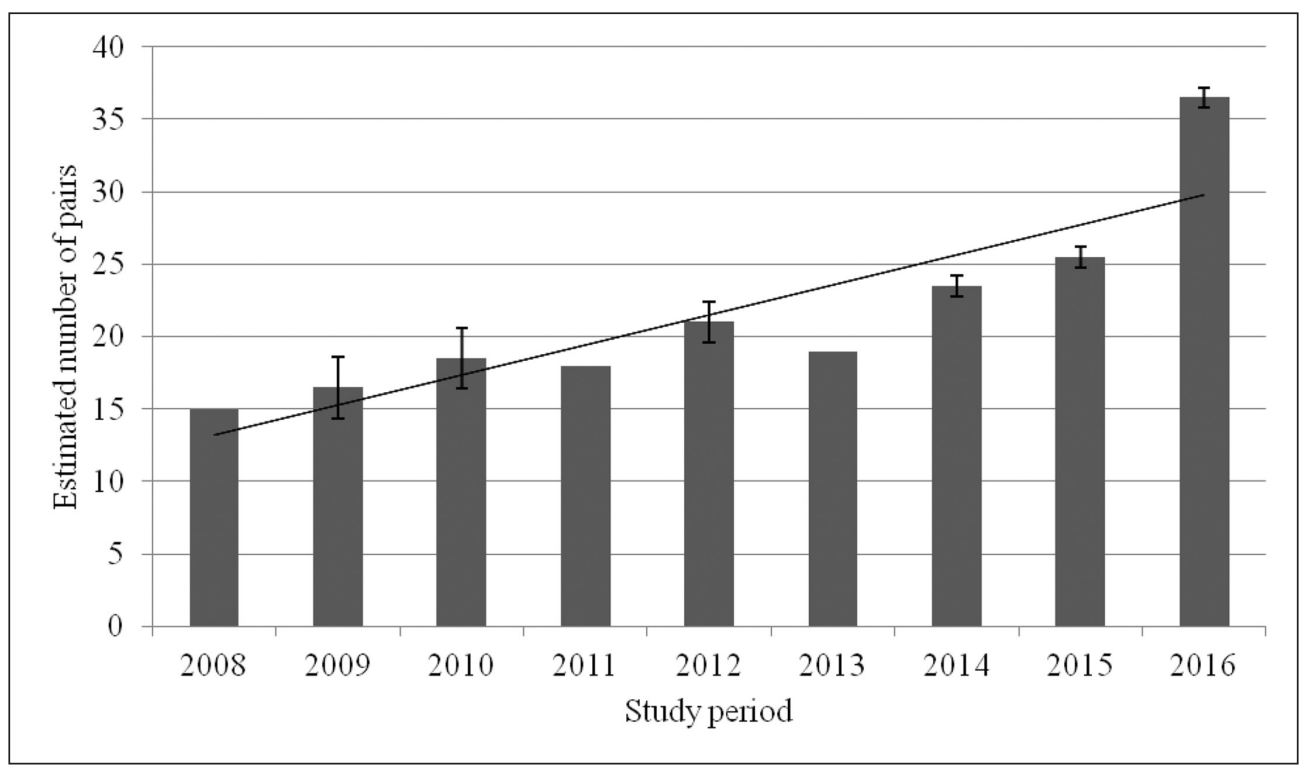

Figure 4. Population trend of Collared Pratincoles in the Nagykunság region during the study period 4. ábra A nagykunsági székicsérpopuláció változásának trendje a vizsgálati időszakban

\section{Discussion}

During the early 1990s, the remaining pratincole populations suffered a further dramatic decline. Moreover, traditional breeding in native steppes gradually disappeared, which might be explained by a number of mutually non-exclusive hypotheses. First, the decline of cattle grazing resulted in the decrease of areas covered by barren alkaline wetlands. Additionally, the marsh vegetation of soda pans and wet grasslands became continous, and insect communities characteristic to open habitats and shallow and water bodies declined and disappeared. Furthermore, the establishment of dykes and ditches led to the draining of temporary steppe wetlands, sinking of the groundwater table, inducing steppe soil formation (Kovács \& Kapocsi 2005).

Behaviours related to nest site selection, colony establishment and breeding have also substantially changed in pratincoles nesting in agricultural landscapes, compared to those breeding in native grasslands. As a result of our analyses, we found a significant relationship between colony size and size of the nearest water body: larger water bodies predicted larger colonies. During the late 1990s, colonies of Eastern Hungary survived only in areas harbouring active rice fields (Oláh \& Széll 1994).

A former hypothesis proposed that food availability in rice fields attracts pratincoles, that in turn form colonies close to rice fields (Széll 1993). We assume that the presence of flying insect fauna connected to temporarily flooded shallow wetlands influenced annual nest site selection in pratincoles. Accordingly, we have repeatedly observed that late or supplementary broods as well as aggregation sites were found in the vicinity of intensively emerging Sympetrum fonscolombei dragonflies. Similarly to our findings, the presence of nearby 
wetlands also predicted colony sites in Spain, where colony sites were determined by the location of suitable arable lands in the neighbourhood of wetlands. Both in natural and agricultural habitats, the majority of colonies were found within a 100 metre range of wetlands (Calvo \& Furness 1995). Therefore the availability of wetlands (including marshes and reedbeds) is vital for pratincole conservation (Calvo 1995).

Our observations match previous findings on the crop type preference of pratincoles nesting in agricultural habitats. In a previous study, pratincoles preferred sunflower, oil pumpkin, silage maize and spring barley fields, fallow and uncultivated land as well as abandoned rice fields (Kovács 1992). Root crops with sparse vegetation available in the vicinity of rice fields were concluded to provide the most suitable nest sites. Prior to our study period, a high proportion of breeding events in Hungary was in sunflower and maize fields (Széll 1993). Although we found clutches in 11 crops of four major crop types, our findings agreed with these general patterns because the proportion of root crops, especially that of sunflower, was significantly higher than that of other crops. The number of clutches found in maize fields was smaller than those found in sunflower plantations, which is explained by larger total cover of the latter plant as it is less responsive to soil conditions. In arable lands of 10-100 hectares located in the vicinity of rice fields, sunflower fields are cultivated each year, attracting prospecting pratincoles by sparsely vegetated soil surfaces. Sunflower was also the most important crop in agricultural areas to Spain, where most of the breeding population was found in sunflower and cotton fields in the south-eastern part of the country. Interestingly, pratincoles regularly establish colonies close to breeding Lapwings, Vanellus vanellus (Calvo \& Furness 1995).

Fallow lands are represented by fallow rice fields in the region, as uncultivated arable lands are rather rare. During spring arrival of pratincoles, these habitats are covered by rice stubble, not attracting prospecting birds. From mid-May onwards, fields are cultivated by heavy disks, creating barren and rugged soil patches, suitable for nesting. Accordingly, fallow rice fields primarily attract late or failed pairs. More than one fourth of clutches were found in this habitat type. During the 1990s and early 2000s, it was not known that pratincoles may breed in dry rice fields. From 2005 onwards, the role of this habitat type has been increasingly important, as these provide nesting opportunities for late and failed breeders (Csíder 2008, Kiss 2011). In our study, we confirmed the preference for root crops, which seems to be unchanged during the past decade. Similar to root crops, fallow lands were also preferred for breeding, with a special respect to fallow rice fields.

Breeding events in spring cereals were recorded rarely. This habitat type was selected by smaller colonies only when open soil patches covered by sporadic vegetation were available, or spring oat fields have not yet germinated prior to spring arrival of pratincoles. Nest in alfalfa or phacelia fields sown in April or May were found only in a few cases. To provide green fertilizers in fallow white rice fields, Alexandria clover and millet are regularly sown in part of the fields in May or early June. Fast-growing crops with high nutrient content are rotated into the soil as green fertilizer, or harvested in August. In drought conditions, these plant develop rather slowly; thus, these fields provide suitable nest sites in barren or sparsely vegetated stages for pratincoles. Therefore a considerable proportion of pratincole nest was found in this crop type. 
Based on previous experiences in Hortobágy habitats, pratincole colonies are established through coordinated exploratory movements, and ensure fast alarming and protection of the nest from approaching predators or intruders (Aradi 1979). Our data show that colonies of 10-30 pairs, that were formerly a general colony size, are no longer typical. Indeed, larger and more closed colonies are established in natural habitats. According to previous studies of pratincole behaviour, colony structure dissolves or completely disappears in agricultural habitats (Kovács \& Kapocsi 2005).

The studied Nagykunság population of pratincoles has been the largest nesting population because the occasionally established colonies in the Kiskunság region and the Szarvas-Gyomaendrőd-Mezőtúr area have been significantly smaller then in the Nagykunság region for many years. The study population therefore is of national importance. Although the size of this nesting population increased slowly since the minimum of 2008, the number of breeding pairs increased considerably in 2016, resulting in a significant population increase during the study period. However, it is not clear whether this increase is driven by natural population increase, movements between colonies in Hungary or immigration from outside the Carpathian Basin.

\section{Acknowledgements}

We are grateful for all of our colleagues who assisted our field work or provided data for our database, or otherwise supported pratincole conservation in Hungary: Ágnes Kovács, Dániel Balla, István Kapocsi, Miklós Lóránt, Péter Öze, Sándor Borza, Sándor Kálmán, Sándor Ujfalusi. Special thanks go to our colleague Antal Széll who is a great theoretical and practical supporter of pratincole conservation.

\section{References}

Aradi, Cs. 1979. Telepesen fészkelő madarak etológiai vizsgálata [Behavioral assessment of colonially breeding bird-species]. - MTA Biológiai Osztály Közleményei 22: 239-256. (in Hungarian)

Bankovics, A., Boros, E., Lóránt, M., Ludnai, T., Németh, Á. \& Pigniczki, Cs. 2015. Madártani megfigyelések és tudományos kutatások [Ornithological observations and researches]. - In: Iványosi, Sz. A. (szerk.) A Kiskunsági Nemzeti Park Igazgatóság negyven éve. - Kiskunsági Nemzeti Park Igazgatóság (in Hungarian)

Berdó, J. 1992. Székicsér (Glareola pratincola) fészkelése Harta-Akasztó pusztán [Breeding of Collared Pratincole (Glareola pratincola) in Harta-Akasztó puszta]. - Partimadár 2: 8. (in Hungarian)

Birdlife International 2015. - www.birdlife.org (in Hungarian)

Bod, P. 1993. Székicsér (Glareola pratincola) eredményes költése Szentes Fertő halastón [Succesfull breeding of Collared Pratincole Glareola pratincola) in Fertö-fishponds, Szentes]. - Partimadár 1: 15-16. (in Hungarian)

Calvo, B. 1994. Effects of agricultural land use on the breeding of Collared Pratincole Glareola pratincola in south-west Spain. - Biological Conservation 70(1): 77-83. DOI: 10.1016/0006-3207(94)90301-8

Calvo, B. 1996. Feeding habitats of breeding Collared Pratincoles Glareola pratincola in Southern Spain. Colonial Waterbirds 19 (special publication 1): 75-77. DOI: $10.2307 / 1521948$

Calvo, B. \& Alberto, L.J. 1990. Nest-site selection of the Collared Pratincole Glareola pratincola in the province of Sevilla, Spain. - Bulletin of the International Wader Study Group 58: 13-15.

Calvo, B. \& Furness, R. W. 1995. Colony and nest-site selection by Collared Pratincoles (Glareola pratincola) in Southwest Spain. - Colonial Waterbirds 18(1): 1-10. DOI: 10.2307/1521393 
Calvo, B. \& Vázquez, M. 1995. Field technique suggestion for the study the Collared Pratincoles Glareola pratincola. - Bulletin of the International Wader Study Group 78: 33-35.

Chernel, I. 1899. Magyarország madarai, különös tekintettel a gazdasági jelentőségökre [Birds of Hungary, particulary their economic significance]. - Magyar Ornithologiai Központ, Budapest, pp. 142-146. (in Hungarian)

Csajbók, J. 2012. Szántóföldi növények termesztése és növényvédelme [Cultivation and pest control of agricultural plants]. - University of Debrecen

http://www.agr.unideb.hu/ebook/szantofoldinovenyek/index.html (in Hungarian)

Csíder, I. 2008. A székicsér (Glareola pratincola) állománya és védelmi helyzete Magyarországon, különös tekintettel a Kisújszállás-Nagyréti populációra [Population trend and conservation of Collared Pratincoles (Glareola pratincola) in Hungary, especially the population of Nagyrét, Kisújszállás's region]. - MSc Thesis, University of Debrecen, https://dea.lib.unideb.hu/dea/handle/2437/96681 (in Hungarian)

Endes, M. 1991. Székicsér (Glareola pratincola) telepes fészkelése Karcag mellett [Collared Pratincole (Glareola pratincola) colonies in region of Karcag]. - Calandrella 5: 87. (in Hungarian)

Hayman, P., Marchant, J. \& Prater, T. 1991. Shorebirds: An Identification Guide to the Waders of the World. - A \& C Black

Kapocsi, I. 2002. Időjárási tényezők hatása a szántóföldi növénykultúrában költő székicsér populációra [The effects of weather conditions the Collared Pratincoles (Glareola pratincola) breeding population]. A Puszta 17: 10-14. (in Hungarian)

Kayser, Y. 2015. Suivi de la reproduction de la Glaréole à collier Glareola pratincola en Camargue et ses environs et actions de conservation pour l'année 2015 [Nature-conservation actions and monitoring activities of of breeding Collared Pratincoles (Glareola pratincola) in Camargue's region at 2015]. - http://www. pole-lagunes.org/sites/default/files/Rapport\%20glareoles\%202015.pdf (in French)

Kiss, Á. 2011. A székicsér (Glareola pratincola) élőhelyválasztása a nagykunsági agrárkörnyezetben [Habitat-selection of Collared Pratincoles (Glareola pratincola) in the Nagykunság region, Hungary]. - MSc Thesis, University of Debrecen (in Hungarian)

Kovács, G. 1992. Mesterséges szikes tavak és szikes kopárok létesítésének módszerei és tapasztalatai a Hortobágyi Nemzeti Parkban [Methods and experiences of making artificial wetlands in the Hortobágy National Park]. - Aquila 99: 155-161. (in Hungarian with English Summary)

Kovács, G. 1993. A székicsér (Glareola pratincola) hortobágyi állományának alakulása [Population trends of Collared Pratincoles (Glareola pratincola) in the Hortobágy National Park]. - Partimadár 1: 16-18. (in Hungarian)

Kovács, G. \& Kapocsi, I. 2005. Székicsér (Glareola pratincola) [Collared Pratincole (Glareola pratincola]. - In: Ecsedi, Z. (szerk.) A Hortobágy madárvilága [Birds of Hortobágy]. - Mezőgazda Kiadó, Budapest, pp. 272-276 (in Hungarian)

Lebedeva, E. A. 1998. Waders in agricultural habitats of European Russia. - International Wader Studies 10: 315-324.

Oláh, J., ifj. \& Széll, A. 1994. A székicsér (Glareola pratincola) fészkelése és védelmi helyzete Magyarországon 1994-ben [Population trends and breeding of Collared Pratincoles (Glareola pratincola) in Hungary at 1994]. - Partimadár 3: 19-21. (in Hungarian)

Pigniczki, Cs. 2000. A székicsér (Glareola pratincola) visszatelepedése a Kiskunság szikes tavaira [Resettlement of the Collared Pratincoles (Glareola pratincola) to soil lakes of Kiskunság]. - Túzok 5: 24-25. (in Hungarian)

R Development Core Team 2016. R: a language and environment for statistical computing R Foundation for Statistical Computing, Vienna, http://www.R-project.org

Rakonczai, Z. 1989. Vörös Könyv - A Magyarországon kipusztult és veszélyeztetett növény- és állatfajok [The Red Book of the Hungarian Flora and Fauna]. - Akadémia Kiadó, Budapest, p. 128. (in Hungarian)

Saveljic, D. 2002. Changes population size of some shorebirds breeding at Ulcinj. - Acrocephalus 23: 39-41.

Sárvári, M. 2011. A rizs termesztése [Cultivation of rice]. - http://www.tankonyvtar.hu/hu/tartalom/tamop425/0010_1A_Book_adaptalt_02_egyeb_gabonanovenyek_termesztese/ch16s04.html (in Hungarian)

Selmeczi-Kovács, Á. 1994. Székicsér (Glareola pratincola) fészkelése Kiskunlacházán [Breeding Collared Pratincoles (Glareola pratincola) in Kiskunlacháza]. - Partimadár 4: 8-9. (in Hungarian)

Sterbetz, I. 1974. Die Brachschwalbe Glareola pratincola [Collared Pratincole Glareola pratincola]. - Die neue Brehm-Bücherei, Ziemsen Verlag, Wittenbarg, Lutherstadt (in German)

Szabó, L. V. 1980. A Hortobágy madárvilága [Birds of Hortobágy]. - Manuscript 1980. 
Széll, A. 1993. A székicsér (Glareola pratincola) fészkelőhely-választása agrár-élőhelyeken [Nest-site selection by Collared Pratincoles (Glareola pratincola) in agricultural environment]. - Partimadár 1: 8-15. (in Hungarian)

Széll, A. 1996. Fokozottan védett állat és védett növényfajok szaporodó közösségeinek előfordulása a Dévaványai Tájvédelmi Körzet térségében [The proliferating occurence of protected animal and plant species in the region of Dévaványai Tájvédelmi Körzet]. - http://www.nimfea.hu/kiadvanyaink/puszta/ szella\%20-\%20vedett\%20dvanya\%20-\%2096.pdf (in Hungarian)

Széll, A. 2014. Székicsér (Glareola pratincola) [Collared Pratincole (Glareola pratincola)]. - In: Haraszthy, L. (szerk.) Natura 2000 fajok és élőhelyek Magyarországon [Natura 2000 species and habitats in Hungary]. - Pro Vértes Közalapítvány, Csákvár, pp. 597-600. (in Hungarian)

Tarján, T. 1934. Székicsér [Collared Pratincole]. - Aquila 38-41: 358. (in Hungarian)

Wetlands International 2015. www.wetlands.org

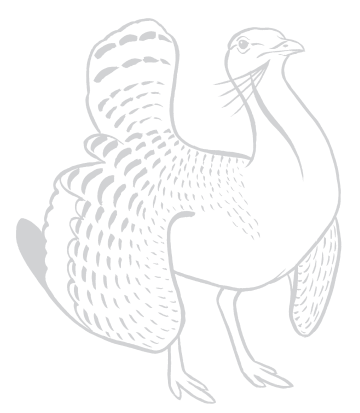

